Stevan Luković1

Marko Savićević ${ }^{2}$

University of Kragujevac, Faculty of Economics
ORIGINAL SCIENTIFIC ARTICLE DOI: 10.5937/ekonomika2103019L

Received: April, 14. 2021.

Accepted: Jun, 18. 2021.

\title{
THE DECLINE OF DEFINED BENEFIT PENSION PLANS IN DEVELOPED COUNTRIES
}

\begin{abstract}
Defined benefit pension plans have played an important role in pension sectors of developed countries in North America, Great Britain and Western Europe for several decades. However, with the beginning of the 21st century, altered demographic trends and global financial market fluctuations have significantly disrupted the financial position of defined benefit pension plans. The aim of this paper is to examine the long-term movement of indicators of the importance of defined benefit pension plans in the pension systems of four developed countries: the United States, Canada, the Netherlands and Great Britain. In these countries defined benefit pension plans still have an important role. The analysis shows that the number of occupational defined benefit pension plans in private sector in the observed countries is declining, along with the continuously decreasing number of participants and increasing problems in achieving a sustainable financial position in the long run.
\end{abstract}

Key words: Defined benefit pension plans, Occupational pension plans, Longterm sustainability, Pension plan funding

JEL classification: G11, G17, J26, J32

\section{СМАЫЕЊЕ ЗНАЧАЈА ПЕНЗИЈСКИХ ПЛАНОВА СА ДЕФИНИСАНИМ ПЕНЗИЈСКИМ НАДОКНАДАМА У РАЗВИЈЕНИМ ЗЕМЉАМА}

\begin{abstract}
Апстракт
Пензијски планови са дефинисаним пензијским надокнадама су у периоду од неколико деценија имали важну улогу у пензијским секторима развијених земаља у Северној Америци, Великој Британији и земљама Западне Европе. Међутим, са почетком 21. века, до изражаја долазе изменени демографски трендови и флуктуације финансијског тржишта које су значајно нарушиле финансијску позищиј пензијских планова са дефинисаним пензијским надокнадама. Циљ рада се огледа у испитивану дугорочног кретања показатеља заступљености пензијских планова са дефинисаним пензијским надокнадама у пензијским системима четири развијене земље: Сједиьене Америчке Државе, Канада, Холандија и Велика Британија. У овим земљама пензијски планови са дефинисаним пензијским надокнадама
\end{abstract}

\footnotetext{
${ }^{1}$ slukovic@kg.ac.rs, ORCID ID 0000-0002-8248-3549

${ }^{2}$ marko.savicevic@kg.ac.rs ORCID ID 0000-0001-5168-1676
} 
и даље имају значајну улогу. Анализом је показано да је број компанијских пензијских планова са дефинисаним пензијским надокнадама у приватном сектору у посматраним земљама у значајном опадању, са све мањим бројем осигураника и све већим проблемима у постизању дугорочно одрживе финансијске позищије.

Кључне речи: Пензијски планови са дефинисаним пензијским надокнадама, Спонзорисани (компанијски) пензијски планови, Дугорочна одрживост, Фундираност пензијских планова

\section{Introduction}

Until the 1990s, defined benefit (DB) pension plans were considered one of the most important institutions of social security in developed countries in North America and Europe. Companies have sponsored DB pension plans to attract and retain the most productive employees. DB pension plans became especially popular during the 1950 s and 1960s when many companies established pension plans. This trend was encouraged by favorable demographic trends (baby boom generation) and macroeconomic parameters. Considering the legally defined obligation of fixed monthly retirement benefit payments inherent to DB pension plans, young population of employees with sustainable average age and life expectancy and a decades-long trend of economic growth provided suitable conditions for the formation of DB pension plans. Thus, occupational DB pension plans in private sector became key carriers of pension insurance in a number of developed countries (e.g., the United States, Canada, Great Britain, the Netherlands, Ireland, Finland and others).

However, starting in the early 1990s, managing DB pension plans became increasingly complex. The main reason lies in demographic factors, i.e., the increase in both life expectancy and the average time period during which pensions are paid to pension plan participants. This trend is specific to all the previously mentioned countries. According to Turner \& Hughes (2008), a large number of occupational pension plans in Ireland were facing problems in financing retirement benefits even during the 1980s. During the 1990s, the share of occupational DB plans' members in total population of employees in private sector declined steadily, although this period was marked by upward trend in global financial market. In Great Britain, from the mid-1990s onwards, a downward trend in the number of defined benefit pension schemes' members was recorded. The decline in the number of occupational DB plans' participants in the United States began during the 1980s, with the simultaneous strengthening of the position of defined contribution (DC) pension plans. A similar development took place in Canada. On the other hand, in countries where the participation in DB plans is mandatory, such as in the Netherlands and Finland, DB plans have shown much greater resilience to demographic trends in terms of both the number of active pension plans and the number of participants.

In the first decade of the 21st century, DB pension plans faced two financial crises: dot.com crisis in 2000-2001 and Global Financial Crisis in 2008. Financial market disruptions have led to a deterioration in the financial position of DB plans. Even in 
the Netherlands, which still has one of the most solvent pension systems in the world, financial shocks have seriously undermined the funded status of pension funds. Hence, one of the most interesting research issues in the field of private pension insurance is the long-term financial sustainability of occupational DB pension plans in private sector.

The paper is organized as follows. In the first part, the theoretical background of the corresponding research issue is provided. The second part presents the methodology used in the analysis. In the third part, overview of indicators of the strength of occupational DB pension plans in North America (the United States and Canada) is given. The fourth part of paper deals with the indicators of the strength of DB pension schemes in Western Europe (Great Britain and the Netherlands). In the final part, conclusions are given.

\section{Theoretical background}

The decline of DB pension plans is well documented in a number of papers (Broadbent, Palumbo \& Woodman, 2006; Munnell, 2008; De Thierry, Lam, Harcourt, Flynn \& Wood, 2014; Mees, 2019). Broadbent, Palumbo and Woodman (2006) examined the shift from DB to DC pension plans in four countries (Australia, Canada, the United Kingdom and the United States) in the period from 1985 to 2005. The authors used the secondary data on number of pension plans, plan members and asset allocation to examine the shift away from DB plans in these countries. The analysis results confirmed the sharp decline of DB pension plans in Australia and the United States, while in the United Kingdom and Canada the decline was confirmed to be less pronounced. Munnell (2008) analyzed the shift from DB to DC plans in the second tier of pension systems in the United States and the United Kingdom in the period from early 1980s to the beginning of the 21 st century. The evidence provided by the author suggests that the shift from DB to DC pension plans is evident in these countries, but has put the retirement security of many individuals at risk. De Thierry, Lam, Harcourt, Flynn and Wood (2014) dealt with the consequences of the decline of DB pension plans for the employers and employees in the United Kingdom, by using critical literature review. Their findings suggest that the gradual shift from DB to DC plans in the United Kingdom began in 1980 s, but the changes in the accounting and disclosure rules in 2001 accelerated this trend. Mees (2019) examined the decline of DB pension schemes in Australia, by using the historical data analysis. The author found that the transition from DB to DC pension plans had been supported with the improved overall financial performance. Contrary to the belief that the decline of DB plans is an adverse outcome to employees, the shift from DB to DC plans was beneficial for Australian workers.

A general consensus exists regarding factors that lie behind the decline. Demographic trends have substantially endangered the financial viability of DB pension plans. The increase in expected life expectancy, although beneficial for the society, poses a challenge for pension plans since they are legally obliged to pay retirement benefits in a longer time period. Between 1960 and 2015, life expectancy for the total population in the United States increased by almost 10 years, from 69.7 years in 1960 to 79.4 years in 2015 (Medina, Sabo \& Vespa, 2020, p. 3). The feature that is particularly important to DB pension plans is the ratio between the inflow of young participants and the overall population of retired participants. According to 
OECD (2020), the share of young population (aged 15 or less) has been continuously decreasing in OECD countries, from $28.4 \%$ in 1970 to merely $17.7 \%$ in 2018 . This limits the ability of pension plans to provide themselves with continuous accrual in active participants. Also, the share of old population (aged 65 or above) has been continuously increasing, from 5.3\% in 1970 to 9.1\% in 2019 (World Bank, 2020). If the demographic structure of insured population in pension plans is reflected in the structure of the global population, this means that pension plans are facing diminishing fraction of young population along with the rapidly growing fraction of older population. Also, the average time period in which benefits are paid substantially impacts the financial position of DB pension plans. For example, according to Office for National Statistics (2019a), life expectancy at age 65 in 1981 for males in Great Britain was 14 years while in 2019 it was 20 years. Projections show that in 2050 life expectancy at age 65 for males in Great Britain will be 22.8 years. These features substantially increase pension obligations that has to be met from DB pension plans' assets in the long run.

\section{Methodology}

Regarding the challenges DB pension plans have been facing in the previous period, it is particularly important to analyze the historical trends concerning the decreasing number of pension plans, decline of the number of the participants and gradual freezing and termination of pension plans. In line with these features, the research question that is to be analyzed in the paper is stated:

Are occupational defined benefit pension plans in private sector able to provide a sustainable financial source for retirement benefits payments to employed population in the long run?

In considering this question, the data on the movements of three relevant indicators in the long-term time horizon are examined, by using the appropriate theoretical argumentation:

1) Number of pension plans and the composition of pension plans' participants - active, inactive and retired;

2) Average funding position of DB pension plans;

3) Position of DB pension plans regarding termination and „freezing” of the pension arrangement.

For the analysis of long-term movements of the selected indicators, secondary data have been used. In the case of the number of pension plans, the composition of pension plans' participants and the funded status available data from national statistical agencies, regulatory agencies and pension supervisors are selected (Employee Benefits Security Administration in the United States, Statistics Canada and the Financial Services Commission of Ontario in Canada, De Nederlandsche Bank in the Netherlands and Department for Work \& Pensions and Office for National Statistics in Great Britain). The periods for which the data were collected vary from country to country due to the availability of data: the United States (1975-2017), Canada (2009-2017), the Netherlands (1997-2019) and Great Britain (1997-2018). 
By examining these indicators, the basic trends in the development of DB pension plans in the future will be pointed out, with a final assessment of their financial sustainability. Data analysis is performed for the four most developed countries in which DB pension plans are still significantly represented in national pension systems (the United States, Canada, the Netherlands and Great Britain). It should be emphasized that these countries were chosen based on criteria of the strength of occupational DB pension plans in private sector. Pension plans from these countries (both public and private) reported the largest assets under management globally with the addition of Australia. However, Australia is excluded from the analysis since DC pension plans are dominant in its pension system while DB pension plans are of minor importance.

\section{The decline of defined benefit pension plans in North America}

Regarding the United States, DB pension plans in the private sector have been generating funding gaps for many years. Figure 1 shows the aggregate funding position of DB pension plans sponsored by Standard\&Poor's 1500 companies between 2007 and 2017. The funded status has been far from satisfactory for many years.

Figure 1: Funding gap and the aggregate funding position of Standard\&Poor's 1500 occupational DB pension plans

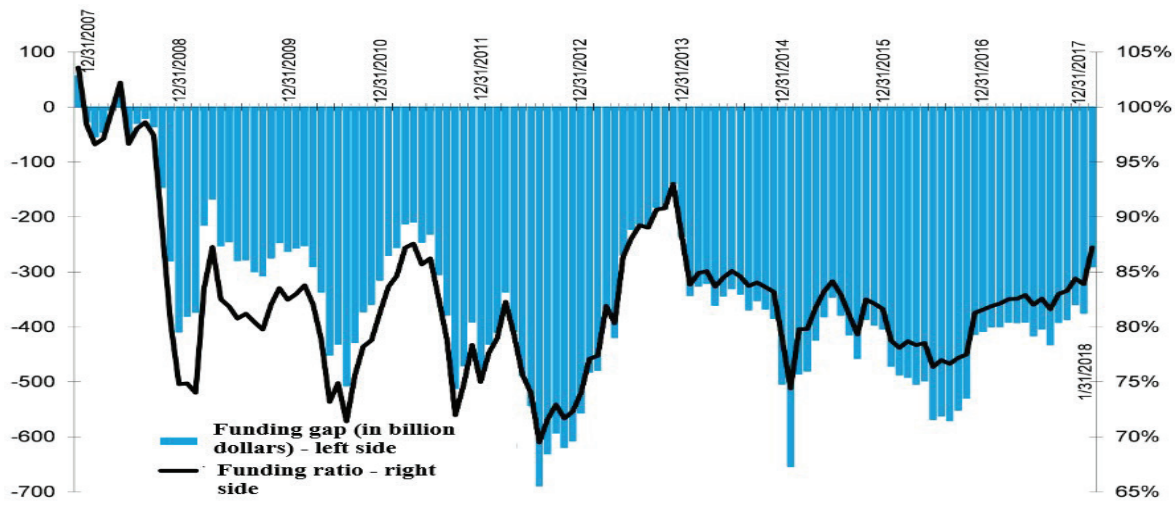

Source: Mercer LLC (2018). S\&P Pension Funded Status Increased. Retrieved October 4, 2020, from https://www.mercer.com/newsroom/january-1500-pension-funded-status-increased.html

Funding gaps in occupational DB plans in the United States became particularly apparent at the beginning of the 21 st century. From Figure 2 it can be seen that the funding position of Fortune $1000 \mathrm{DB}$ pension plans was satisfactory until the dot.com crisis in 2001. However, the dot.com crisis adversely affected the funded status of U.S. pension plans. The entire period until 2007 is characterized by rising but insufficient funding levels. An improvement in the funded status was recorded in 2007 due to property investments and housing bubble, but then in 2008 the funding gap rose again. Unlike dot.com crisis in 2001, from the effects of which pension plans recovered in the following years, Global Financial Crisis has damaged the financial position of pension plans in the long run, as the funded status has not improved to date. 
Figure 2: Funded status of Fortune 1000 occupational DB pension plans, 2000-2010

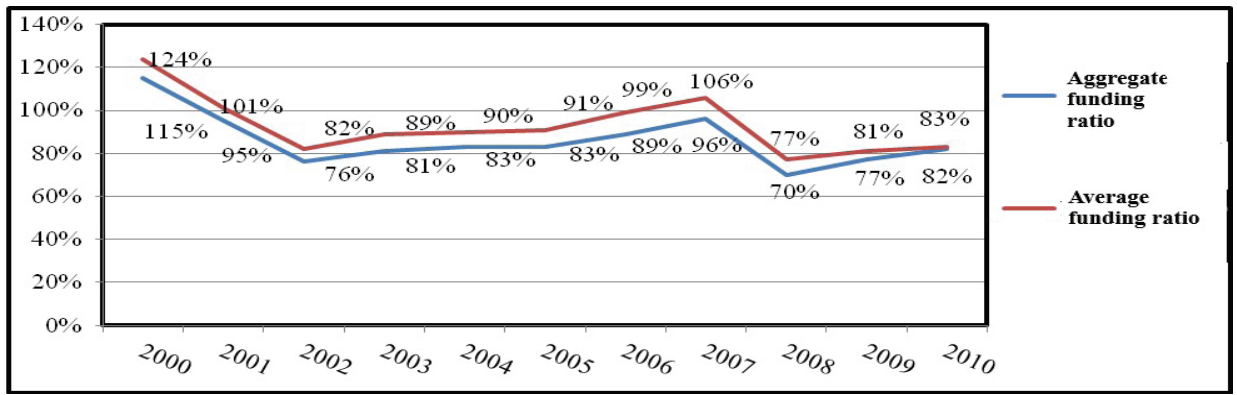

Source: Warshawsky, M. (2012). Corporate Defined Benefit Pension Plans and the Financial

Crisis: Impacts, and Sponsor and Government Reactions. In R. Maurer, O. Mitchell \& M Warshawsky (Eds.), Reshaping Retirement Security: Lessons from the Global financial Crisis (pp. 161-187). Oxford, UK: Oxford University Press, p. 163

Contrary to the trend of increasing funding gaps, which is particularly evident after the beginning of the Global Financial Crisis, the decreasing trend in the number of DB pension plans in the private sector and the number of active members in these plans is of a longer-term nature. Table 1 reports the number of DB pension plans in the United States between 1975 and 2015 that has been continuously decreasing since the mid-1980s (in the late 1970s legal framework for the inception of DC pension plans was introduced).

Table 1: Number of occupational DB pension plans in US, number of active members, pension plan assets, contributions, and benefit payments, 1975- 2017

\begin{tabular}{l|c|c|c|c|c|c} 
& $\begin{array}{c}\text { Number } \\
\text { of DB } \\
\text { plans }\end{array}$ & $\begin{array}{c}\text { Number of } \\
\text { members } \\
\text { (thousands) }\end{array}$ & $\begin{array}{c}\text { Number } \\
\text { of active } \\
\text { members } \\
\text { (thousands) }\end{array}$ & $\begin{array}{c}\text { Pension } \\
\text { plans' assets } \\
\text { (\$ millions) }\end{array}$ & Contributions & $\begin{array}{c}\text { Benefits } \\
\text { disbursed (\$ millions) } \\
\text { millions) }\end{array}$ \\
\hline $\mathbf{1 9 7 5}$ & 20,035 & 33,004 & 27,214 & 185,950 & 24,242 & 12,903 \\
\hline $\mathbf{1 9 8 0}$ & 24,505 & 37,979 & 30,100 & 401,455 & 42,626 & 22,148 \\
\hline $\mathbf{1 9 8 5}$ & 24,742 & 39,692 & 28,895 & 826,117 & 41,996 & 54,466 \\
\hline $\mathbf{1 9 9 0}$ & 19,242 & 38,832 & 26,205 & 961,904 & 23,026 & 66,363 \\
\hline $\mathbf{1 9 9 5}$ & 17,087 & 39,736 & 23,395 & $1,402,079$ & 41,423 & 85,134 \\
\hline $\mathbf{2 0 0 0}$ & 13,557 & 41,613 & 22,218 & $1,986,177$ & 33,369 & 127,510 \\
\hline $\mathbf{2 0 0 5}$ & 11,557 & 41,925 & 20,310 & $2,254,032$ & 92,662 & 136,555 \\
\hline $\mathbf{2 0 1 0}$ & 10,155 & 41,423 & 17,172 & $2,448,361$ & 131,055 & 169,645 \\
\hline $\mathbf{2 0 1 5}$ & 8,715 & 37,286 & 14,405 & $2,862,402$ & 108,552 & 235,800 \\
\hline $\mathbf{2 0 1 6}$ & 8,394 & 36,028 & 13,866 & $2,923,233$ & 124,484 & 232,395 \\
\hline $\mathbf{2 0 1 7}$ & 8,090 & 34,960 & 13,475 & $3,208,820$ & 158,963 & 243,439
\end{tabular}

Source: Employee Benefits Security Administration (2018). Private Pension Plan Bulletin Historical Tables and Graphs. United States Department of Labor

This trend has been accompanied by a continuous decrease in the number of active members (paying contributions individuals). Total number of members (active, inactive 
and retired) decreased, but to a much lesser extent, which means that in the same period there was an increase in the number of retired and inactive members. As a result, annual contributions have been significantly lower than annually disbursed retirement benefits since the mid-1980s, and this trend has continued to date.

When considering the liquidation and freezing of pension plans, it should be noted in the first place that these are not the same procedures. Pension plan termination implies that the sponsor is released from all costs and obligations regarding pension plan contractual agreement. A pension plan enters the termination procedure if it has been insufficiently funded in the prolonged time period or if the pension plan sponsor is financially distressed. Company shifts the burden of retirement obligations to the government agency that guarantees the payment of retirement benefits. A sponsor can also terminate fully funded pension plan, but in that case the accumulated retirement benefits must be paid, as a lump-sum payment or by purchasing lifelong annuities (Levine \& Golumbic, 2014). The termination procedure is complex and involves a large number of different costs. Hence, sponsors more often decide to freeze the pension plan. This procedure takes several forms, such as: closing the pension plan for the admission of new members, preventing future increases in benefits for active members attributed to additional years of working career or salary growth (so-called "hard freeze") or allowing increases in pensions benefits only for salary growth (so-called "soft freeze").

Table 2: The evolution of Fortune 500 DB pension plans, 2000-2019

\begin{tabular}{|c|c|c|c|c|c|c|c|c|c|c|}
\hline & 2000 & 2001 & 2002 & 2003 & 2004 & 2005 & 2006 & 2007 & 2008 & 2009 \\
\hline Open & $95 \%$ & $93 \%$ & $92 \%$ & $89 \%$ & $84 \%$ & $79 \%$ & $72 \%$ & $62 \%$ & $58 \%$ & $52 \%$ \\
\hline Closed & $2 \%$ & $3 \%$ & $3 \%$ & $5 \%$ & $7 \%$ & $10 \%$ & $13 \%$ & $18 \%$ & $19 \%$ & $21 \%$ \\
\hline Frozen & $3 \%$ & $4 \%$ & $4 \%$ & $6 \%$ & $9 \%$ & $10 \%$ & $14 \%$ & $18 \%$ & $22 \%$ & $26 \%$ \\
\hline Terminated & $<1 \%$ & $<1 \%$ & $<1 \%$ & $<1 \%$ & $<1 \%$ & $1 \%$ & $1 \%$ & $1 \%$ & $1 \%$ & $1 \%$ \\
\hline & 2010 & 2011 & 2012 & 2013 & 2014 & 2015 & 2016 & 2017 & 2018 & 2019 \\
\hline Open & $48 \%$ & $43 \%$ & $39 \%$ & $36 \%$ & $32 \%$ & $29 \%$ & $28 \%$ & $26 \%$ & $25 \%$ & $23 \%$ \\
\hline Closed & $22 \%$ & $23 \%$ & $24 \%$ & $24 \%$ & $24 \%$ & $24 \%$ & $22 \%$ & $23 \%$ & $23 \%$ & $22 \%$ \\
\hline Frozen & $28 \%$ & $32 \%$ & $34 \%$ & $37 \%$ & $41 \%$ & $42 \%$ & $44 \%$ & $45 \%$ & $46 \%$ & $46 \%$ \\
\hline Terminated & $2 \%$ & $2 \%$ & $2 \%$ & $3 \%$ & $3 \%$ & $4 \%$ & $5 \%$ & $5 \%$ & $6 \%$ & $8 \%$ \\
\hline
\end{tabular}

Source: McFarland, B. (2020). Retirement offerings in the Fortune 500: 1998-2019. Insider, 30(6). Willis Towers Watson, p. 3

The share of pension plans involved with the termination or freezing has increased since the beginning of the 21st century. According to McFarland (2020), in 2019 as much as $46 \%$ of Fortune 500 companies (the 500 largest US companies) have frozen their retirement plans, and $22 \%$ of the retirement plans were closed to the admission of new members (Table 2). In addition, $8 \%$ of companies have been sponsoring terminated pension plans in 2019 , and only $23 \%$ of companies kept their pension plans open to new entrants.

Regarding occupational DB plans in Canada, in the last decade there have been some doubts regarding their sustainability in the future. Although DB pension plans from public sector and private sector still comprise almost $80 \%$ of the total number of 
the insured employees, the number of new DB pension plans has been continuously decreasing from year to year. Also, an increasing number of existing plans are becoming closed to new members. Pension plan sponsors are progressively shifting toward DC pension plans. Although the declining trend of the importance of DB pension plans in Canada has not been as rapid as in the United States, there are expectations that it will accelerate in the future.

As in other countries, unfavorable demographic trends in Canada have led to the maturation of pension plans, given that the insured population is getting older on average. As a result, pension liabilities are continuously rising. On the other hand, financial market fluctuations at the beginning of the 21 st century have reduced investment returns, causing the deterioration of financial position of DB plans. Government regulations in Canada require pension plan sponsor to make additional contributions to the pension plan if there is a large funding gap, which significantly increases the cost of sponsoring the pension plan.

Figure 3: Mercer Pension Health index, 1999-(Q1)2020

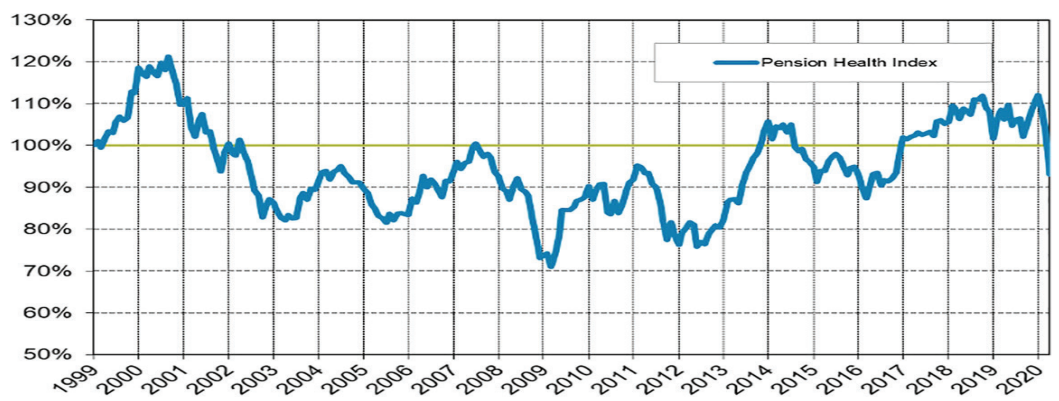

Source: Mercer LLC (2020). A long month in the long life of Defined Benefit plans as markets react to coronavirus pandemic. Retrieved October 5, 2020, from https://www.mercer.ca/en/ newsroom/defined-benefit-plans-plummet-in-q1.html

For the assessment of the funded status of pension plans in Canada, Mercer Pension Health Index is used. This indicator is calculated as the ratio of assets and pension liabilities for the modeled pension plan. At the beginning of the observed period, this indicator is arbitrarily set at the level of $100 \%$. In the following time periods index is calculated under the assumptions that the paid contributions are equal to the sum of the normal cost (servicing cost) and additional payments in case of a funding gap of pension plan, and that there are no further adjustments in the pension arrangement. Figure 3 shows that the funded status of DB pension plans in Canada was satisfactory at the beginning of the 21 st century, as the funding level was approximately $120 \%$. In the following years the index has decreased, so that, in the period from 2002 to 2014 , DB pension plans have been facing a problem of insufficient funding. In the last few years, the funded status of DB pension plans has improved, due to favorable trends in the stock market and the long-term bond market, but the funding level is still lower than at the beginning of the 21 st century (about $112 \%$ at the end of 2019).

The problem of insufficient funding has become especially relevant with the onset of the Global Financial Crisis. Table 3 shows the trends in the number of insufficiently 
funded pension plans and the number of participants in pension plans in the province of Ontario in Canada, in the period from 2009 to 2017, based on annual DB pension plan funding reports periodically published by the Financial Services Commission of Ontario. It can be noticed that the problem of insufficient funding has been gradually mitigated since 2014. However, in 2017 every fifth pension plan from the observed sample was insufficiently funded. In addition, what is particularly worrying is the fact that approximately half of the participants in the observed sample of pension plans were members of underfunded DB pension plans.

Table 3: Number of underfunded pension plans and the number of participants in the underfunded pension plans in Ontario, Canada, 2009-2017

\begin{tabular}{c|c|c|c|c|c} 
& $\begin{array}{c}\text { Number of } \\
\text { pension plans }\end{array}$ & $\begin{array}{c}\text { Underfunded } \\
\text { plans }\end{array}$ & $\begin{array}{c}\text { Number of } \\
\text { participants in } \\
\text { the underfunded } \\
\text { pension plans }\end{array}$ & $\begin{array}{c}\text { Share of } \\
\text { underfunded } \\
\text { pension plans }\end{array}$ & $\begin{array}{c}\text { Share of } \\
\text { participants in } \\
\text { the underfunded } \\
\text { pension plans }\end{array}$ \\
\hline $\mathbf{2 0 0 9}$ & 1,539 & 605 & - & $39 \%$ & - \\
\hline $\mathbf{2 0 1 0}$ & 1,506 & 682 & $1,074,141$ & $45 \%$ & $58 \%$ \\
\hline $\mathbf{2 0 1 1}$ & 1,438 & 752 & $1,182,681$ & $52 \%$ & $65 \%$ \\
\hline $\mathbf{2 0 1 2}$ & 1,387 & 753 & $1,264,105$ & $54 \%$ & $69 \%$ \\
\hline $\mathbf{2 0 1 3}$ & 1,361 & 687 & $1,300,179$ & $50 \%$ & $70 \%$ \\
\hline $\mathbf{2 0 1 4}$ & 1,311 & 471 & $1,168,013$ & $36 \%$ & $64 \%$ \\
\hline $\mathbf{2 0 1 5}$ & 1,283 & 396 & $1,109,485$ & $31 \%$ & $60 \%$ \\
\hline $\mathbf{2 0 1 6}$ & 1,333 & 395 & $1,089,889$ & $30 \%$ & $58 \%$ \\
\hline $\mathbf{2 0 1 7}$ & 1,378 & 304 & 961,965 & $22 \%$ & $51 \%$
\end{tabular}

Source: Financial Services Commission of Ontario (2018). Report on the Funding of Defined Benefit Pension Plans in Ontario. Retrieved October 3, 2020, from http://www.fsco.gov.on.ca/en/pensions/actuarial/Pages/risk-based_supervision.aspx

Beside the share of insufficiently funded pension plans in the total number of pension plans, it is important to determine the magnitude of the funding gaps. Table 4 shows the distribution of funding level in the observed sample of pension plans, in the period from 2007 to 2017 . It can be observed that the share of pension plans with a funding level of less than 60\% was particularly high in 2008 (approximately 8\%), but also in 2011, when almost every tenth pension plan faced a grave funding gap. However, in the following years the share of pension plans with an extremely low funding level dropped significantly.

Table 4: Funded status of occupational DB pension plans in Ontario, Canada, 2007-2017

\begin{tabular}{c|c|c|c|c|c|c} 
& $<\mathbf{6 0} \%$ & $\mathbf{6 0 \% - 8 0 \%}$ & $\mathbf{8 0 \% - 9 0 \%}$ & $\mathbf{9 0 \% - 1 0 0 \%}$ & $\mathbf{1 0 0 \% - 1 2 0 \%}$ & $>\mathbf{1 2 0} \%$ \\
\hline $\mathbf{2 0 0 7}$ & $2.0 \%$ & $17.6 \%$ & $33.5 \%$ & $27.0 \%$ & $15.2 \%$ & $4.7 \%$ \\
\hline $\mathbf{2 0 0 8}$ & $7.7 \%$ & $53.0 \%$ & $18.9 \%$ & $10.0 \%$ & $7.7 \%$ & $2.7 \%$ \\
\hline $\mathbf{2 0 0 9}$ & $2.1 \%$ & $41.0 \%$ & $36.9 \%$ & $12.2 \%$ & $6.0 \%$ & $1.8 \%$ \\
\hline $\mathbf{2 0 1 0}$ & $1.7 \%$ & $31.2 \%$ & $40.9 \%$ & $17.4 \%$ & $6.7 \%$ & $2.1 \%$ \\
\hline $\mathbf{2 0 1 1}$ & $10.6 \%$ & $65.0 \%$ & $15.6 \%$ & $4.8 \%$ & $2.8 \%$ & $1.2 \%$ \\
\hline $\mathbf{2 0 1 2}$ & $6.0 \%$ & $66.1 \%$ & $18.6 \%$ & $5.2 \%$ & $2.2 \%$ & $1.9 \%$ \\
\hline $\mathbf{2 0 1 3}$ & $0.8 \%$ & $8.4 \%$ & $28.7 \%$ & $38.1 \%$ & $21.7 \%$ & $2.3 \%$ \\
\hline
\end{tabular}




\begin{tabular}{l|l|l|l|l|l|l}
\hline $\mathbf{2 0 1 4}$ & $2.8 \%$ & $32.6 \%$ & $19.7 \%$ & $19.1 \%$ & $21.8 \%$ & $4.0 \%$ \\
\hline $\mathbf{2 0 1 5}$ & $5.4 \%$ & $30.0 \%$ & $23.8 \%$ & $20.8 \%$ & $16.1 \%$ & $3.9 \%$ \\
\hline $\mathbf{2 0 1 6}$ & $1.6 \%$ & $13.4 \%$ & $38.2 \%$ & $32.3 \%$ & $12.0 \%$ & $2.4 \%$ \\
\hline $\mathbf{2 0 1 7}$ & $3.3 \%$ & $11.2 \%$ & $30.3 \%$ & $34.0 \%$ & $17.5 \%$ & $3.7 \%$
\end{tabular}

Source: Financial Services Commission of Ontario (2018). Report on the Funding of Defined Benefit Pension Plans in Ontario. Retrieved October 3, 2020, from http://www.fsco.gov.on.ca/en/pensions/actuarial/Pages/risk-based_supervision.aspx

The situation is similar with pension plans with funding levels in the range $60 \%$ $80 \%$ and $80 \%-90 \%$. In 2009 , the number of pension plans that had a funding level greater than $120 \%$ was relatively low, but this number continued to increase in the following period. In 2017, approximately $21 \%$ of the total number of observed pension plans were fully funded and overfunded, while almost $4 \%$ of pension plans had an extraordinary funded status (greater than $120 \%$ ), compared to only $1.2 \%$ in 2011 . On the other hand, the fact that is raising concerns is the share of underfunded pension plans (funding level less than $100 \%$ ) that at 2017 stood at approximately $79 \%$.

Due to the aforementioned trends, the number of occupational DB pension plans in Canada had been continuously declining between 2009 and 2017, which can be seen in Figure 4. This trend was particularly pronounced from 2011 onwards. In the same period, the number of active members in DB pension plans had been decreasing.

Figure 4: Number of DB pension plans and active members in Canada, 2009-2017
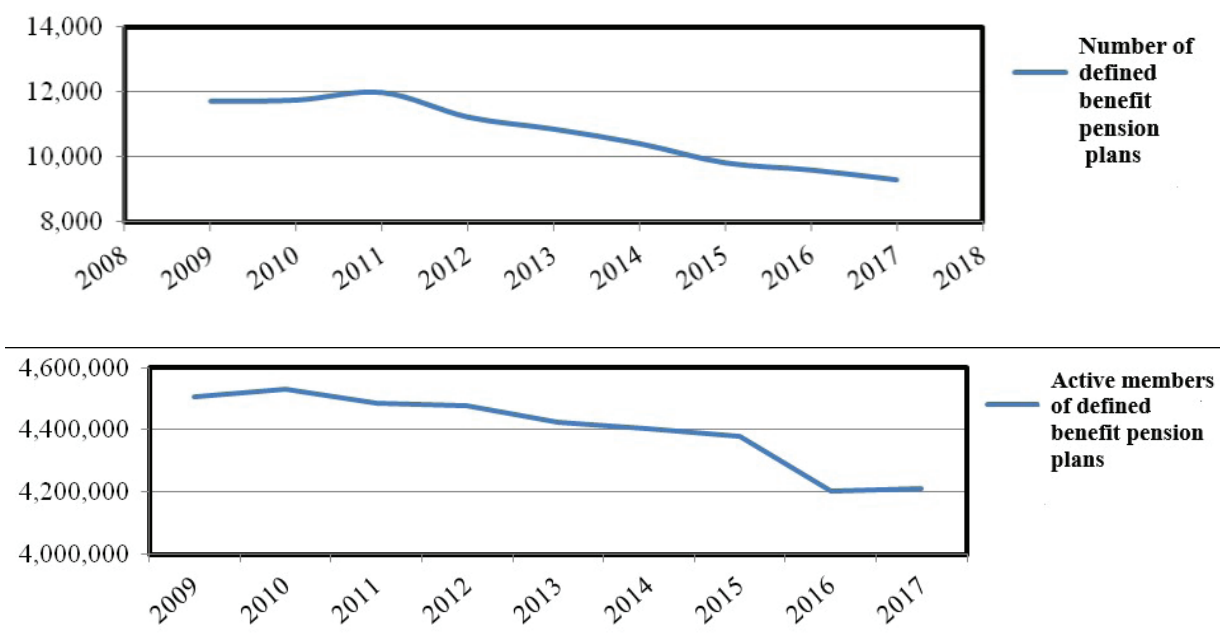

Source: Statistics Canada (2020a). Registered pension plans (RPPS), active members and market value of assets by special retirement conditions. Retrieved October 4, 2020, from https:// www150.statcan.gc.ca/t1/tbl1/en/cv.action?pid=1110006201

This trend had been particularly pronounced in DB pension plans in the private sector, unlike the public sector. Although the number of active members decreased, the 
market value of assets in DB pension plans shows an upward trend between 2009 and 2017 (Figure 5). This trend can be explained by favorable developments in Canadian financial market in the observed period, i.e., the stabilization of the financial market after 2009. In the last few years, the market value of assets is in a phase of stagnation, which is a consequence of the declining number of active members and the amount of paid contributions.

Figure 5: Market value of assets of occupational DB pension plans in Canada, 2009-2017 (CAD million)

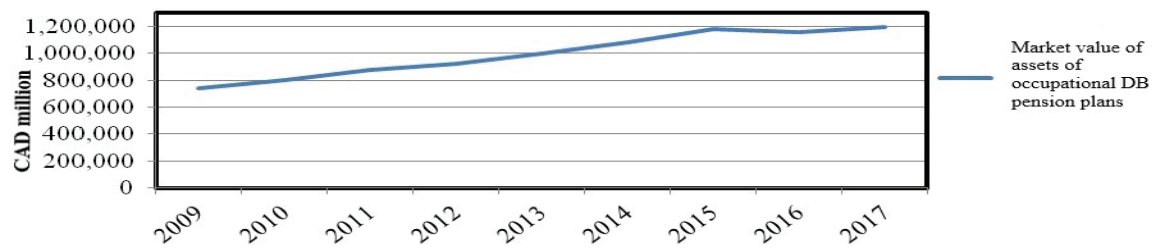

Source: Statistics Canada (2020b). Registered pension plans (RPPS), active members and market value of assets by age and service condition for special retirement. Retrieved October 4, 2020, from https://www150.statcan.gc.ca/t1/tbl1/en/cv.action?pid $=1110006301$

\section{Decline of defined benefit pension plans in Western Europe}

The average funding level of Dutch pension funds in 2007 was an extraordinary 1.46 (the funding ratio of 1 indicates that the pension plan is fully funded at the moment of valuation), while in 2008 the average funding level decreased to 1.02 (Figure 6). It should be noticed that even after ten years the funded status has not considerably improved, so the average funding ratio in mid-2018 was 1.084 , which is substantially lower compared to funded status before the Global Financial Crisis (De Nederlandsche Bank, 2018). In addition, approximately $25 \%$ of the total number of pension funds do not meet the statutory minimum funding level criterion (104.2\% in 2018). A special problem lies in the fact that insufficiently funded pension funds have 3.2 million active members, 1.9 million pension retirees and 4.1 million inactive members, which is approximately $50 \%$ of the total number of DB pension funds' participants in the Netherlands.

The number of pension funds in the Netherlands is continuously declining. According to PricewaterhouseCoopers (2017), the total number of pension funds (industry-wide, mandatory occupational and voluntary occupational) fell from more than a thousand funds at the end of 1997 to only 268 pension funds in 2017 (Figure 7). 
Figure 6: Funding level of Dutch DB pension plans, 2007-2013
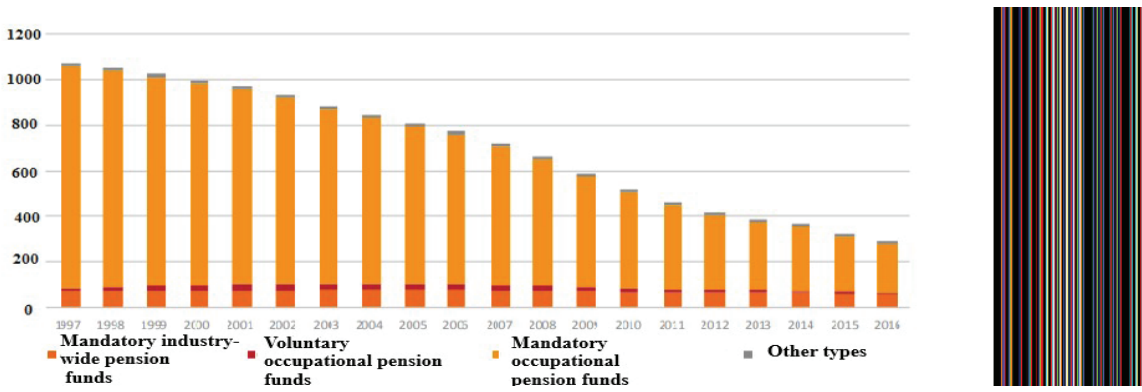

Source: De Haan, L. (2015). Recovery measures of underfunded pension funds: higher contributions, no indexation, or pension cuts. Journal of Pension Economics \& Finance, 17(4), p. 438

These developments are caused by the consolidation of Dutch pension fund sector, i.e., the merger of small pension funds with large pension funds. The consolidation of the pension insurance sector made possible for newly formed pension funds to operate with low costs, due to the use of economies of scale. In addition, major innovations have been introduced in the Dutch pension system in the past few years, which have additionally affected the pension fund sector. The formation of general pension funds (so-called APFs) in early 2016, as a special type of pension funds for one or more companies (which may or may not be part of the same business group), further increased the competitive pressure that "traditional" occupational pension funds have been facing.

Figure 7: Number of DB pension funds in the Netherlands, 1997-2016

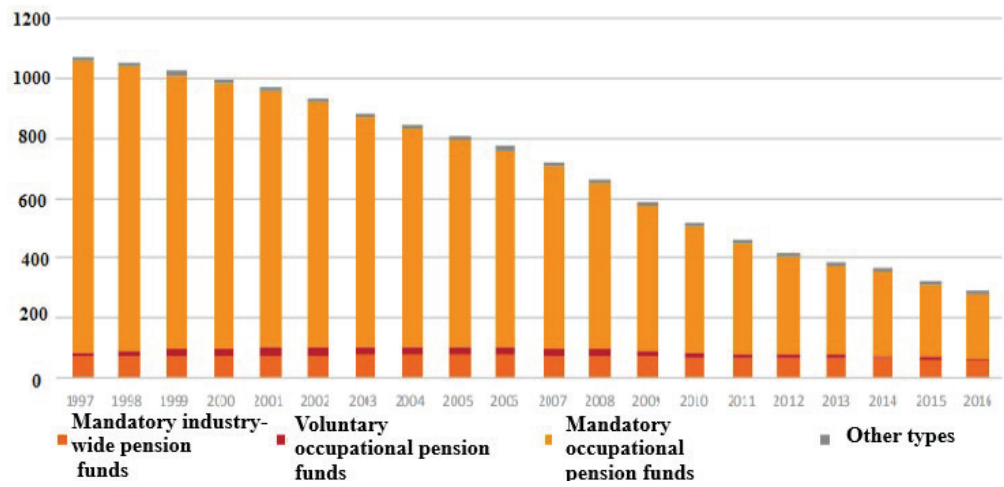

Source: PricewaterhouseCoopers (2017). Pension 2025 - Scenarios for the future of the pension sector. p. 10

Dutch employers have been increasingly establishing a hybrid form of pension funds, the so-called "collective defined contribution pension schemes". In these schemes, the retirement benefit is calculated by using the pension formula, in which the basis for calculation is the average salary during the working career. However, unlike traditional DB pension plans, the employer has no additional financial obligations if the investment returns are lower than expected. Longevity risk and investment risk are borne by the 
participants. On the other hand, unlike defined contribution pension plans, there are no individual pension accounts, but all the assets are consolidated in a single pension fund, thus reducing unit costs. Due to the introduction of new pension schemes, the number of active members in traditional pension funds has been continuously declining.

Table 5: Number and composition of Dutch DB pension funds'members, 2007-2020(in thousands)

\begin{tabular}{l|c|c|c|c} 
& Active members & Final salary & Average salary & Combined \\
\hline $\mathbf{2 0 0 7}$ & 5,459 & 189 & 5,204 & 66 \\
\hline $\mathbf{2 0 0 8}$ & 5,406 & 74 & 5,261 & 71 \\
\hline $\mathbf{2 0 0 9}$ & 5,373 & 63 & 5,250 & 60 \\
\hline $\mathbf{2 0 1 0}$ & 5,373 & 60 & 5,256 & 57 \\
\hline $\mathbf{2 0 1 1}$ & 5,434 & 55 & 5,325 & 54 \\
\hline $\mathbf{2 0 1 2}$ & 5,363 & 36 & 5,275 & 52 \\
\hline $\mathbf{2 0 1 3}$ & 5,226 & 33 & 5,143 & 50 \\
\hline $\mathbf{2 0 1 4}$ & 5,213 & 22 & 5,047 & 54 \\
\hline $\mathbf{2 0 1 5}$ & 5,000 & 5 & 4,959 & 36 \\
\hline $\mathbf{2 0 1 6}$ & 4,947 & 11 & 4,912 & 24 \\
\hline $\mathbf{2 0 1 7}$ & 4,957 & 11 & 4,943 & 3 \\
\hline $\mathbf{2 0 1 8}$ & 4,938 & 11 & 4,926 & 1 \\
\hline $\mathbf{2 0 1 9}$ & 5,093 & 10 & 5,082 & 1 \\
\hline $\mathbf{2 0 2 0}$ & 5,212 & 12 & 5,199 & 1
\end{tabular}

Source: De Nederlandsche Bank Database (2020a). Number of active members in thousands.

Retrieved October 1, 2020, from https://statistiek.dnb.nl/en/downloads/index.aspx\#/details/ pension-agreements-year/dataset/d2c03ef8-1d7a-4132-bc31-35ab45588fdf/resource/4cd41bde-

\section{$134 d-4257-8 e 23-9259 b 1902 b b a$}

From Table 5, it can be seen that in the period from 2007 to 2020 the number of participants in pension funds in which the final salary pension formula is used for the calculation of retirement benefits decreased. The situation is similar for the combined approach (different combinations of final salary and the average salary pension formula). In 2020, participants for whom the pension is calculated by using the average salary pension formula dominated the total population of pension funds'participants. In the same period, due to unfavorable demographic trends, an increase in the number of inactive and retired participants occured, which was accompanied by a simultaneous previously stated decrease in the number of active participants (Figure 8). 
Figure 8: Number of active, inactive and retired members in Dutch industry-wide and occupational DB pension plans, 1997-2019

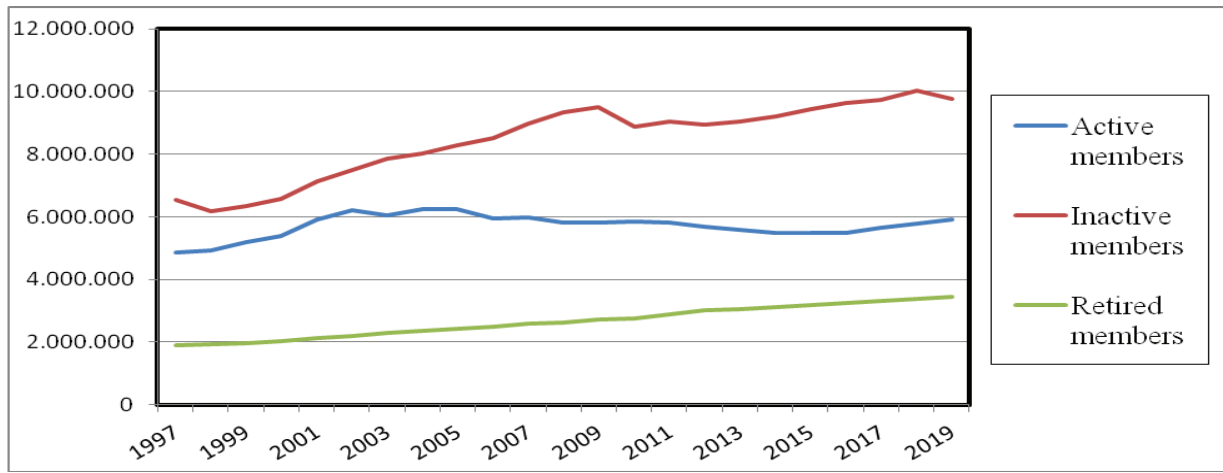

Source: De Nederlandsche Bank Database (2020b). Total Pension Funds. Retrieved October 1, 2020 from https://statistiek.dnb.nl/en/downloads/index.aspx\#/details/number-of-pension-fundmembers/dataset/d2f52a5d-130b-45c0-b3b5-3b148b3a034c/resource/c585c951-4d2f-433e-9431$5 f 63 d b b c a 8 c b$

As for Great Britain, the declining trend in the importance of DB pension schemes has long-term characteristics that are similar to the trend observed in the United States. Table 6 reports that the number of active participants in DB pension schemes in the private sector has been continuously decreasing in the period from 2000 to 2018. It should be noticed that the overall number of active members in private occupational pension plans rose in the same period, from 5.7 million in 2000 to 11.0 million in 2018 . Also, the number of members in occupational pension schemes in private and public sector rose from 10.1 million in 2000 to 17.3 million in 2018.

Table 6: Number of active members of occupational DB and DC pension schemes in Great Britain, 2000- 2018 (millions)

\begin{tabular}{c|c|c|c|c|c} 
& Private sector & $\begin{array}{c}\text { DB pension } \\
\text { schemes }\end{array}$ & DC pension schemes & Public sector & Total \\
\hline $\mathbf{2 0 0 0}$ & 5.7 & - & - & 4.4 & 10.1 \\
\hline $\mathbf{2 0 0 5}$ & 4.7 & 3.7 & 1.0 & - & - \\
\hline $\mathbf{2 0 1 0}$ & 3.0 & 2.1 & 1.0 & 5.3 & 8.3 \\
\hline $\mathbf{2 0 1 1}$ & 2.9 & 1.9 & 0.9 & 5.3 & 8.2 \\
\hline $\mathbf{2 0 1 2}$ & 2.7 & 1.7 & 1.0 & 5.1 & 7.8 \\
\hline $\mathbf{2 0 1 3}$ & 2.8 & 1.6 & 1.2 & 5.3 & 8.1 \\
\hline $\mathbf{2 0 1 4}$ & 4.9 & 1.6 & 3.2 & 5.4 & 10.2 \\
\hline $\mathbf{2 0 1 5}$ & 5.5 & 1.6 & 3.9 & 5.6 & 11.1 \\
\hline $\mathbf{2 0 1 6}$ & 7.7 & 1.3 & 6.4 & 5.7 & 13.5 \\
\hline $\mathbf{2 0 1 7}$ & 8.8 & 1.1 & 7.7 & 6.3 & 15.1 \\
\hline $\mathbf{2 0 1 8}$ & 11.0 & 1.1 & 9.9 & 6.3 & 17.3
\end{tabular}

Source: Office for National Statistics (2019b). Occupational Pension Schemes Survey, UK: 2018. p. 6 
On the other hand, in the same period the number of active participants in private DC pension plans and in public pension plans has been increasing (the upward trend is particularly evident in DC plans, starting with the introduction of automatic enrolment in 2013). Although the number of active participants in DB pension schemes is continuously decreasing, the number of inactive and retired participants did not decrease significantly in the observed period (Figure 9).

Figure 9: Composition of the insured population in occupational $D B$ pension schemes in Great Britain, 2004-2016

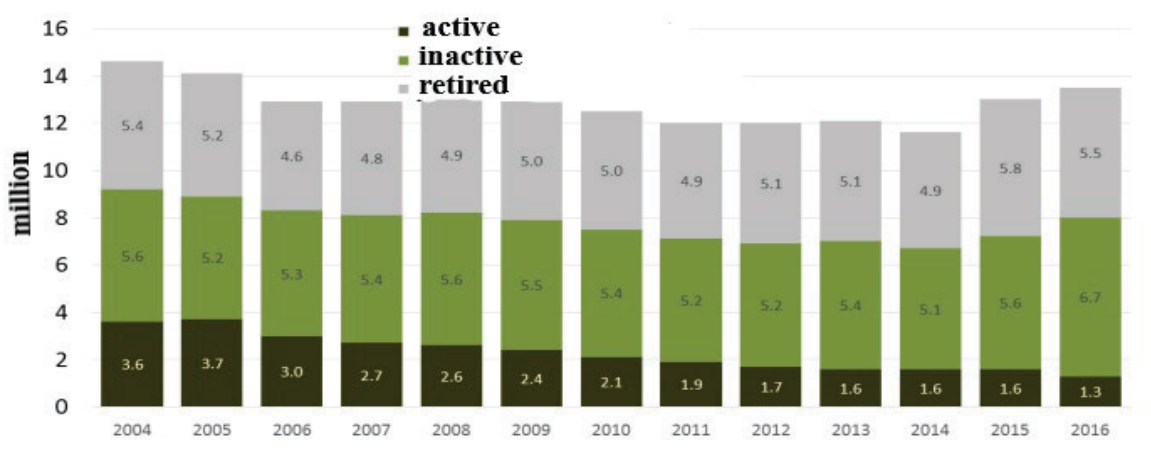

Source: Thurley, D. \& Mor, F. (2018). Defined Benefit Pension Schemes - 2018 White Paper. Briefing Paper, No. CBP-8219. House of Commons, p. 6

Moreover, the number of inactive participants in the period from 2004 to 2016 increased from 5.6 million to 6.7 million. Such developments have caused a deterioration in the financial position of pension schemes, given the rising gap between the amount of contributions and pension liabilities.

Figure 10: Gap between pension liabilities and assets of DB pension schemes in Great Britain, 2006-2016

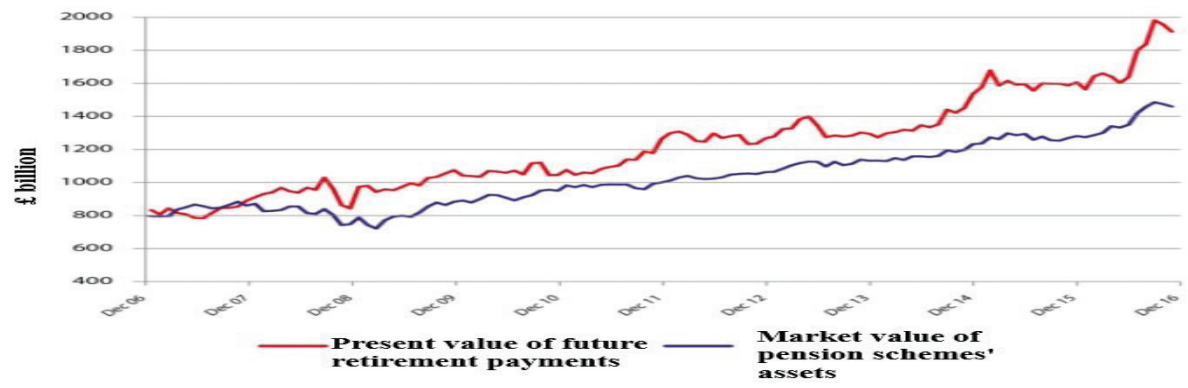

Source: Department for Work \& Pensions (2017). Security and Sustainability in Defined Benefit Pension Schemes. Williams Lea Group on behalf of the Controller of Her Majesty's Stationery Office, p. 25 
Figure 10 shows the trend of continuous increase in the gap between the value of pension liabilities and the market value of DB plans' assets since 2007. Accordingly, the funding position of pension schemes is becoming increasingly unfavorable. In addition, the fact that the funding problem has worsened in the past few years is particularly worrying, as can be seen in Figure 11, which shows the deficits of pension schemes sponsored by the FTSE 350 companies.

Figure 11: Funding gap of FTSE 350 DB pension schemes, 2015-2017

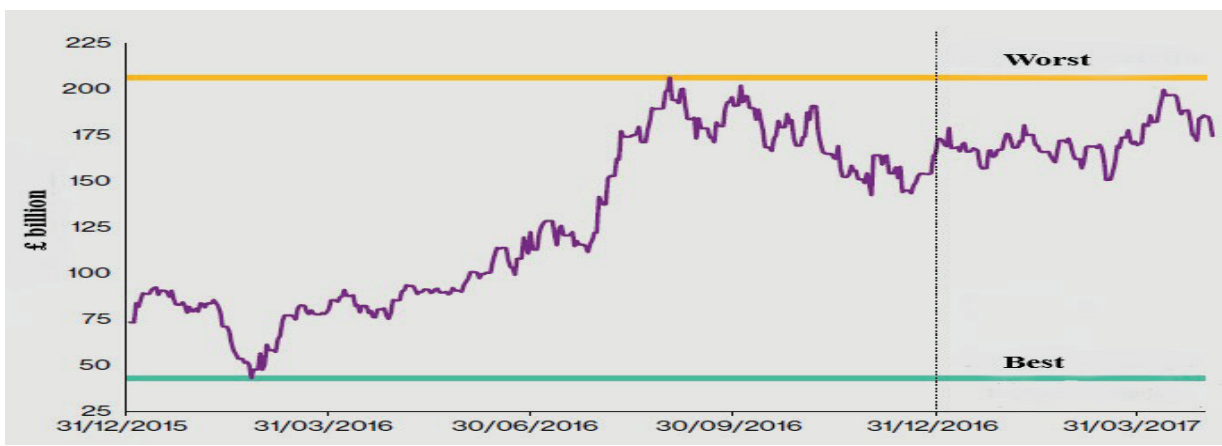

Source: Willis Towers Watson (2017). FTSE 350 DB Pension Scheme Survey 2017, p. 6

In Figure 11 it can be seen that the funding gap of pension schemes in only one year (end of 2015 - end of 2016) increased from 50 billion pounds to as much as 200 billion pounds, and that in the following period a slight decrease in the funding gap occurred.

As it can be seen from the previous discussion, the decline of DB pension plans has been particularly pronounced in the United States and Great Britain. The number of pension plans and pension plans' members has been continuosly declining during the past two decades, while the funded status has been worsening in the same period. This is in line with the previous research efforts carried out by Broadbent, Palumbo and Woodman (2006) and Munnell (2008). Also, the decline is much less noticeable in Canada and the Netherlands which is in consistence with the conclusions given in Munnell (2008). Unlike pension plans in the United States and Great Britain, pension plans in Canada and Netherlands are still reporting satisfactory funded status, though the number of active members has decreased in both countries, while the number of retired and deffered members is on the rise.

\section{Conclusion}

Over the last two decades, the shift from DB pension plans to DC pension plans and hybrid pension plans has become evident. In some countries (e.g., Great Britain and the United States), this trend is encouraged through regulation (automatic enrollment or employer's matched contributions in DC pension plans). The number of newly opened DB pension plans is decreasing from year to year, which suggests that the pure DB pension model is outdated. However, DB pension plans still have an important role in 
the global financial market. This is supported by the fact that most of the largest pension plans globally are defined benefit pension plans. The size of DB pension plans can be attributed to the decades-long investing in financial market and accumulation of assets.

The decline of DB pension plans is particularly striking in the private sector. In the public sector, occupational DB plans will continue to be a dominant model of pension insurance. The level of their dominance will depend on the ability of government, which is ultimately the public pension plans' sponsor, to compensate for the funding gaps of pension plans and guarantee the payment of retirement benefits to public servants. In private sector, companies that sponsor pension plans guarantee the payment of retirement benefits with their own business income, without the possibility of transferring that risk to a third party in the long run.

Based on the presented data for four countries with the most developed occupational DB pension plans, it can be seen that their financial position has significantly deteriorated in the previous period, not only regarding the number of participants but also the longterm financial sustainability. The analyzed trends in the observed countries are of a decades-long property, without significant possibilities for their reversal in the future, especially when it comes to demographic factors. In addition, it should be stated that in the observed countries private sector is dominant with a large number of companies that have sponsored DB pension plans for decades. The trend of freezing and termination of pension plans, which became particularly evident after the Global Financial Crisis, implies that companies are less and less oriented towards preserving DB pension plans.

As for the scientific contribution of the paper, it should be emphasized that, to the best of the authors' knowledge, this research issue has not yet been analyzed in the Republic of Serbia, although there are many research efforts internationally that dealt with this subject. The main weakness of the paper is the absence of the empirical analysis. By using some of the statistical tests to prove the existence of the downward trend in the importance of DB pension plans, an empirical confirmation could be obtained that would improve the quality of the paper. This remark also provides the recommendation to further research.

\section{References}

Broadbent, J., Palumbo, M., \& Woodman, E. (2006). Defined Benefit to Defined Contribution Pension Plans - Implications for Asset Allocation and Risk Management. Prepared for a Working Group on Institutional Investors, Global Savings and Asset Allocation, Committee on the Global Financial System. Retrieved October 6, 2020 from https://www.bis.org/publ/wgpapers/cgfs27broadbent3.pdf

De Haan, L. (2015). Recovery measures of underfunded pension funds: higher contributions, no indexation, or pension cuts. Journal of Pension Economics \& Finance, 17(4). 437-468. doi:10.1017/S1474747216000287

De Nederlandsche Bank (2018). Dutch Pension Funds' policy funding ratio rises to $108.4 \%$. DNB Statistical News, July 2018. Retrieved September 21, 2020, from https://www. dnb.nl/en/news/news-and-archive/Statistischnieuws2018/dnb378007.jsp 
De Nederlandsche Bank Database (2020a). Number of active members in thousands. Retrieved October 1, 2020, from https://statistiek.dnb.nl/en/downloads/index. aspx\#/details/pension-agreements-year/dataset/d2c03ef8-1d7a-4132-bc3135ab45588fdf/resource/4cd41bde-134d-4257-8e23-9259b1902bba

De Nederlandsche Bank Database (2020b). Total Pension Funds. Retrieved October 1, 2020 from https://statistiek.dnb.nl/en/downloads/index.aspx\#/details/numberof-pension-fund-members/dataset/d2f52a5d-130b-45c0-b3b5-3b148b3a034c/ resource/c585c951-4d2f-433e-9431-5f63dbbca8cb

Department for Work \& Pensions (2017). Security and Sustainability in Defined Benefit Pension Schemes. London, UK: Williams Lea Group on behalf of the Controller of Her Majesty's Stationery Office

De Thierry, E., Lam, H., Harcourt, M., Flynn, M., \& Wood, G. (2014). Defined benefit pension decline: the consequences for organizations and employees. Employee Relations, 36(6), 654-673. DOI/10.1108/ER-02-2013-0020

Employee Benefits Security Administration (2018). Private Pension Plan Bulletin Historical Tables and Graphs. Washington, US: United States Department of Labor

Financial Services Commission of Ontario (2018). Report on the Funding of Defined Benefit Pension Plans in Ontario. Retrieved October 3, 2020, from http://www. fsco.gov.on.ca/en/pensions/actuarial/Pages/risk-based_supervision.aspx

Levine, D., \& Golumbic, L. (2014). Freezing Defined Benefit Plans. Retrieved September 14, 2020,

from https://www.groom.com/wp-content/uploads/2017/09/733_Freezing_Defined Benefit_Plans_.pdf

McFarland, B. (2020). Retirement offerings in the Fortune 500: 1998-2019. Insider, 30(6). 12-24

Medina, L., Sabo, S., \& Vespa, J. (2020). Living Longer: Historical and Projected Life Expectancy in the United States, 1960 to 2060. Population Report P25-1145. U.S. Department of Commerce

Mees, B. (2019). Risk shifting and the decline of defined benefit pension schemes in Australia. Accounting History Review, 30(1), 69-87. DOI.org/10.1080/2155285 1.2020 .1711527

Mercer LLC (2018). S\&P Pension Funded Status Increased. Retrieved October 4, 2020, from https://www.mercer.com/newsroom/january-1500-pension-fundedstatus-increased.html

Mercer LLC (2020). A long month in the long life of Defined Benefit plans as markets react to coronavirus pandemic. Retrieved October 5, 2020, from https://www. mercer.ca/en/newsroom/defined-benefit-plans-plummet-in-q1.html

Munnell, A. (2008). Employer-sponsored plans: The shift from defined benefit to defined contribution. In G. Clark, A. Munnell \& M. Orszag (Eds.), The Oxford Handbook of Pensions and Retirement Income (pp. 359-380). Oxford, UK: Oxford University Press 
PricewaterhouseCoopers (2017). Pension 2025 - Scenarios for the future of the pension sector

OECD (2020). Young population (indicator). Paris, France: OECD Publishing. doi: $10.1787 / 3 \mathrm{~d} 774 \mathrm{f} 19$-en

Office for National Statistics (2019a). Past and projected period and cohort life tables, 2018-based, UK: 1981 to 2068. Retrieved November 1, 2020, from https://www. ons.gov.uk/peoplepopulationandcommunity//lifeexpectancies/bulletins/pastand projecteddatafromtheperiodandcohortlifetables/1981 to2068

Office for National Statistics (2019b). Occupational Pension Schemes Survey, UK: 2018

Pjanić, M., \& Lučić, D. (2012). Reforma penzijskog sistema Srbije u uslovima ekonomsko-finansijske krize. Anali Ekonomskog fakulteta u Subotici, (28), 109122.

Statistics Canada (2020a). Registered pension plans (RPPs), active members and market value of assets by special retirement conditions. Retrieved October 4, 2020, from https://www150.statcan.gc.ca/t1/tbl1/en/cv.action?pid=1110006201

Statistics Canada (2020b). Registered pension plans (RPPs), active members and market value of assets by age and service condition for special retirement. Retrieved October 4, 2020, from https:/www150.statcan.gc.ca/t1/tbl1/en/ cv.action? $=1110006301$

Thurley, D., \& Mor, F. (2018). Defined Benefit Pension Schemes - 2018 White Paper. Briefing Paper, No. CBP - 8219, London, UK: House of Commons

Turner, J., \& Hughes, G. (2008). Large Declines in Defined Benefit Plans Are Not Inevitable: The Experience of Canada, Ireland, the United Kingdom, and the United States. Discussion Paper, PI-0821. London, UK: The Pensions Institute, Cass Business School

Warshawsky, M. (2012). Corporate Defined Benefit Pension Plans and the Financial Crisis: Impacts, and Sponsor and Government Reactions. In R. Maurer, O. Mitchell \& M Warshawsky (Eds.), Reshaping Retirement Security: Lessons from the Global Financial Crisis (pp. 161-187). Oxford, UK: Oxford University Press. DOI: 10.1093/acprof:oso/9780199660698.001.0001

Willis Towers Watson (2017). FTSE 350 DB Pension Scheme Survey 2017. London, UK: WTW

World Bank (2020). Population ages 65 and above (\% of total population). Retrieved November 16, 2020, from https://data.worldbank.org/indicator/SP.POP.65UP. TO.ZS 
